\title{
Cultural Guidelines for Commercial Production of Interiorscape Aglaonema ${ }^{1}$
}

\author{
Jianjun Chen, Dennis B. McConnell, Richard J. Henny, and Kelly C. Everitt ${ }^{2}$
}

The genus Aglaonema belongs to the family Araceae and comprises 21 species. All species are open-pollinated, herbaceous evergreens native to the humid and heavily shaded tropical forests of southeast Asia, northeast India, southeren China, Indonesia, and New Guinea. Due to the attractive foliar variegation and tolerance to low light, Aglaonema have been cultivated in China and other Asian countries for centuries as plants of good fortune. Thus, Aglaonema plants are commonly referred to as Chinese Evergreens. They were introduced into the western world in 1885 .

Commercial production of Aglaonema cultivars in Florida started in the 1930s but it took almost 30 years before their ability to survive under interior low light conditions became widely recognized by interiorscapers. The increased interior use is also attributed to a continuing release of attractive interspecific hybrids. For example, a total of 29 Aglaonema hybrids received U.S. patents during the 1990s. The intent of this article is to describe common Aglaonema species and cultivars in the foliage plant industry (See Table 1), provide guidelines on their culture and interior use, and list physiological problems encountered in both production and in the interiorscape (See Table 3).

\section{Cultural Guidelines}

\section{Propagation}

The rooting of cuttings and division of basal shoots or suckers are the main methods of Aglaonema propagation since micropropagation (tissue culture) has not been successful with this genus. Cuttings should have four to five leaves and root best in well-aerated media (air space of 10 to $20 \%$ ) with a $\mathrm{pH}$ of 5.5 to 6.5 and soluble salts of 1.0 to $1.5 \mathrm{dS} / \mathrm{m}$. Currently, many unrooted cuttings are purchased from Central America and Caribbean nurseries. Cuttings should always be carefully inspected before sticking, as conditions during shipping may spread plant pathogens.

During propagation, the containers with cuttings should be kept off the ground to improve drainage. Cultivars vary in sucker production; some produce more than four, while others produce none. Consequently, cultivars producing the most suckers

1. This document is ENH957, one of a series of the Environmental Horticulture Department, Florida Cooperative Extension Service, Institute of Food and Agricultural Sciences, University of Florida. Original publication date July 30, 2003. Visit the EDIS Web Site at http://edis.ifas.ufl.edu.

2. Jianjun Chen, Assistant Professor, Mid-Florida Research and Education Center and Environmental Horticultural Department, Dennis B. McConnell, Professor, Environmental Horticultural Department, Richard J. Henny, Professor, Mid-Florida Research and Education Center and Environmental Horticultural Department, and Kelly C. Everitt, Research Assistant, Mid-Florida Research and Education Center at the Institute of Food and Agricultural Sciences, University of Florida.

The Institute of Food and Agricultural Sciences is an equal opportunity/affirmative action employer authorized to provide research, educational information and other services only to individuals and institutions that function without regard to race, color, sex, age, handicap, or national origin. For information on obtaining other extension publications, contact your county Cooperative Extension Service office. Florida Cooperative Extension Service/Institute of Food and Agricultural Sciences/University of Florida/Christine Taylor Waddill, Dean. 
are grown in larger numbers, as more propagules are available for division.

\section{Production}

Quality Aglaonema production can be achieved with media comprised of sphagnum peat, pine bark, vermiculate, or perlite with a bulk density between 0.2 to $0.8 \mathrm{~g} / \mathrm{cm}^{3}$ (dry weight), a total porosity of 50 to $75 \%$, a moisture content of 50 to $75 \%$, and air space of 10 to $20 \%$. Media $\mathrm{pH}$ should range from 6.0 to 6.5 and soluble salts of 1 to $2.5 \mathrm{dS} / \mathrm{m}$ when root-zone solution is extracted by the pour-through method. Aglaonema should be grown in $75 \%$ to $90 \%$ shade (3,000 to 1,250 foot candles). Leaves of most Aglaonema cultivars lose color and are held in an upright vertical position when grown under the upper end of the suggested light range. Consequently most Aglaonema growers use 80 to $90 \%$ shade. Air temperatures below $55^{\circ} \mathrm{F}$ may cause chilling injury in Aglaonema, particularly 'Silver Queen'. Detailed information on cultivar response to chilling can be found at:

http://edis.ifas.ufl.edu/pdffiles/EP/EP10300.pdf.

Either controlled-released or water-soluble fertilizers with micronutrients, or a combination of both, can be used for Aglaonema production. The appropriate ratio of $\mathrm{N}: \mathrm{P}_{2} \mathrm{O}_{5}: \mathrm{K}_{2} \mathrm{O}$ should be $3: 1: 2$. The suggested application rate is 2 to $2.5 \mathrm{lb} \mathrm{N}$ per $1,000 \mathrm{sq} f t$ per month or 150 to $200 \mathrm{ppm} \mathrm{N}$ using a water-soluble complete fertilizer. A supplemental micronutrient fertilizer may be needed, as most Aglaonema cultivars are prone to develop copper and other microelement deficiencies. Growers are recommended to monitor media soluble salts and $\mathrm{pH}$ every 2 or 3 weeks using the pour-through method. If the soluble salts reading is $1 \mathrm{dS} / \mathrm{m}$, the plant will show nutrient deficiency if no fertilizer is provided during growing season; if the soluble salts reading is $2 \mathrm{dS} / \mathrm{m}$, nutrient levels are adequate; and if the reading is $3 \mathrm{dS} / \mathrm{m}$ or above, reduce either the rate or frequency of fertilizer application; in some cases, leaching media with water is necessary to reduce soluble salt buildup. Table 2 provides a guide for determining if Aglaonema cultivars are appropriately fertilized based on leaf analysis. It is advisable to stop fertilizing one month before shipment. Media should be kept moist with a container capacity of 50 to $80 \%$.

\section{Shipping and Interior Care}

As mentioned previously, Aglaonema cultivars are generally sensitive to chilling temperatures, and air temperatures below $55^{\circ} \mathrm{F}$ during shipping can damage their leaves. Leaves of some cultivars are prone to mechanical damage during shipping. Thus, shipping boxes should be used to minimize plant movement.

Once plants are placed in interior conditions, only minimal maintenance is required. Aglaonema cultivars can tolerate a light level as low as 25 foot candles but should never be placed in full sun or the leaves will be scorched. A supply of a 20-20-20 water soluble fertilizer solution with a $\mathrm{N}$ level at 50 ppm once a month should be adequate under interior conditions. Over-fertilization indoors will cause soluble salts buildup and lead to leaf margin or tip injury. The soil should be kept moist but not saturated. When inflorescences appear (a spathe and spadix in the center of the foliage), it is best to remove them. This aids plant longevity and keeps the plant full. The foliage will get dusty and most interiorscapers either wipe the leaves with a damp, lint-free cloth periodically or use a light spray of leaf polish. Pruning is not necessary. However, dead or yellowing leaves should be removed. Plants should be rotated every 1-2 weeks within the cache pot to maintain symmetry. 
Table 1. A listing of Aglaonema cultivars available in Florida as of 2002.

\begin{tabular}{|c|c|}
\hline $\begin{array}{l}\text { Cultivar or Common } \\
\text { Name }\end{array}$ & Characteristics \\
\hline 'Abidjan' & This cultivar appears as a broad-leaf version of 'Jubilee' and can grow to 40 inches tall. \\
\hline 'Amelia' & $\begin{array}{l}\text { It is more dense than other cultivars and can grow to } 36 \text { inches tall hosting deep green } \\
\text { foliage with random spots of pale green. }\end{array}$ \\
\hline 'B. J. Freeman' & $\begin{array}{l}\text { Also known as 'Cecelia', this cultivar has a wide stature, fragile leaves, and a higher light } \\
\text { requirement. }\end{array}$ \\
\hline 'Black Lance' & $\begin{array}{l}\text { Its lanceolate leaves are deep green surrounded by a jagged strip of silver straddling the } \\
\text { midvein. It has an upright habit to } 36 \text { inches tall. Tall leaves tend to droop in lower light } \\
\text { levels, and it is extremely chill sensitive. }\end{array}$ \\
\hline 'Brilliant' & $\begin{array}{l}\text { This mid-sized cultivar has a lot of bright white color and very few maintenance } \\
\text { requirements. }\end{array}$ \\
\hline 'Cory' & $\begin{array}{l}\text { This is another mid-sized cultivar with a feather-like pattern of silver and green foliage } \\
\text { with cream-colored stems. }\end{array}$ \\
\hline 'Deborah' & $\begin{array}{l}\text { Wide and mid-sized, the centers of the leaves are grey with dark green margins, gold } \\
\text { veins, and cream-colored stems. }\end{array}$ \\
\hline 'Emerald Beauty' & See 'Maria'. \\
\hline 'Emerald Star' & $\begin{array}{l}\text { One of the tallest of the Aglaonema cultivars, it has an upright habit with dark, wide, } \\
\text { glossy leaves with yellow green speckles. Tolerates chilling temperatures. }\end{array}$ \\
\hline 'Golden Bay' & $\begin{array}{l}\text { It suckers heavily and can become dense. It can handle temperatures as low as } 45^{\circ} \mathrm{F} \\
\text { with minimal damage. The leaf is very pale green with a deeply colored margin. }\end{array}$ \\
\hline 'Green Lady' & $\begin{array}{l}\text { Stocky yet symmetrical. The leaves are deep green with lighter green jagged stripes } \\
\text { emanating from the midvein. It suckers well. }\end{array}$ \\
\hline 'Illumination' & $\begin{array}{l}\text { The stems are cream colored. The leaves are silvery with deep green vertical striping } \\
\text { straddling the gold midvein. }\end{array}$ \\
\hline 'Jewel of India' & $\begin{array}{l}\text { This silver cultivar is very tall, symmetrical and full, and it suckers well. Tolerates chilling } \\
\text { temperatures. }\end{array}$ \\
\hline 'Jubilee' & $\begin{array}{l}\text { This one has a comparatively higher light requirement. It is deep green with a wide silver } \\
\text { streak }\end{array}$ \\
\hline 'Jubilee Petite' & $\begin{array}{l}\text { Short, compact, and full, this cultivar has a pale green center reaching to the tips with a } \\
\text { bit of deeper green on the sides of the leaves. }\end{array}$ \\
\hline 'Maria' & Its leaves are dark green and grey, and it has a compact habit. \\
\hline 'Maria Christina' & This cultivar looks like a more compact version of its parent, 'Silver Queen'. \\
\hline 'Mary Ann' & This stocky cultivar is deep green with silver stripes terminating just before the margins. \\
\hline 'Painted Princess' & $\begin{array}{l}\text { This heavily suckering cultivar stays compact and full throughout its life. It has deep } \\
\text { green leaves striped with almost transparent grey. }\end{array}$ \\
\hline 'Patricia' & This cultivar has a spiky appearance and almost entirely silver leaves. \\
\hline 'Peacock' & The leaves have patterns similar to a peacock's feathers. \\
\hline 'Queen of Siam' & $\begin{array}{l}\text { A cream-stemmed, flimsier version of 'Deborah', it is very large and suckers when it is } \\
\text { cut back. Its leaves are medium green with grey centers. }\end{array}$ \\
\hline
\end{tabular}


Table 1. A listing of Aglaonema cultivars available in Florida as of 2002.

\begin{tabular}{|c|c|}
\hline $\begin{array}{l}\text { Cultivar or Common } \\
\text { Name }\end{array}$ & Characteristics \\
\hline 'Rhapsody in Green' & $\begin{array}{l}\text { Similar to 'Black Lance', this cultivar has stockier leaves with a splotch of silver in the } \\
\text { center. It is enormous and durable. }\end{array}$ \\
\hline 'Romana' & $\begin{array}{l}\text { A mid-sized cultivar that was originally sold as 'Manila'. It tends to root first before } \\
\text { suckering and cannot tolerate high humidity. }\end{array}$ \\
\hline 'Royal Ripple' & $\begin{array}{l}\text { This one resembles a darker 'Silver Queen'. It is mid-sized and maintains its color } \\
\text { patterns in low light. }\end{array}$ \\
\hline 'San Remo' & In color, this is the darkest of the Aglaonema. \\
\hline 'Silver Bay' & $\begin{array}{l}\text { Grey dominates the leaf while it is bordered in a basic shade of green. Leaves are more } \\
\text { ovate than other cultivars. It suckers heavily with an upright, boxy habit and prefers } \\
\text { lower light. }\end{array}$ \\
\hline 'Silver Queen' & $\begin{array}{l}\text { The most common of the cultivars, it has alternating green and silver splotched stripes. } \\
\text { One of the most chilling-sensitive cultivars. }\end{array}$ \\
\hline 'Silver Ribbon' & This tri-colored cultivar has undulating, narrow leaves. \\
\hline 'Silverado' & $\begin{array}{l}\text { The striking green margin borders a leaf whose color fades from light green to white as it } \\
\text { approaches the midvein. }\end{array}$ \\
\hline 'Stars' & $\begin{array}{l}\text { Similar to 'Emerald Star', its leaves have deep green and cream random spotting. It } \\
\text { tends to get top heavy. Tolerates chilling temperatures. }\end{array}$ \\
\hline 'Stripes' & It has blatant banding of white along the veins of the leaves. \\
\hline 'White Lance' & White stems and dense, narrow leaves with pale colors are its main features. \\
\hline 'White Rain' & $\begin{array}{l}\text { It is dense, suckers well, and will not thin. The leaves are wider and deeper in color } \\
\text { when compared with 'White Lance' but patterning is more similar to 'Deborah'. }\end{array}$ \\
\hline
\end{tabular}

Table 2. Nutrient concentrations in leaves that are generally considered low, medium, or high for Aglaonema growth.

\begin{tabular}{|l|l|l|l|}
\hline \hline Nutrient & Low & Medium & High \\
\hline Nitrogen (\%) & $<2.5$ & $2.5-3.5$ & $>3.5$ \\
\hline Phosphorus (\%) & $<0.2$ & $0.2-0.8$ & $>0.8$ \\
\hline Potassium (\%) & $<2.5$ & $2.5-5.0$ & $>5.0$ \\
\hline Calcium (\%) & $<1.0$ & $1.0-2.5$ & $>2.5$ \\
\hline Magnesium (\%) & $<0.3$ & $0.3-0.8$ & $>0.8$ \\
\hline Sulfur (\%) & $<0.2$ & $0.2-0.8$ & $>0.8$ \\
\hline Iron (ppm) & $<50$ & $50-300$ & $>300$ \\
\hline Manganese (ppm) & $<30$ & $30-200$ & $>200$ \\
\hline Zinc (ppm) & $<15$ & $15-200$ & $>200$ \\
\hline Copper (ppm) & $<10$ & $10-80$ & $>80$ \\
\hline Boron (ppm) & $<15$ & $15-50$ & $>50$ \\
\hline \hline
\end{tabular}


Table 3. Causes and effects of various physiological problems.

\begin{tabular}{|c|c|c|}
\hline Symptoms & Cause & Treatment \\
\hline $\begin{array}{l}\text { Grey spots that turn dark and } \\
\text { greasy appear on leaves. }\end{array}$ & Chilling injury. & $\begin{array}{l}\text { Prevention is best since this usually occurs in } \\
\text { shipping or during cooler weather. Avoid drafts } \\
\text { and low temperatures. Injury occurs } 3-7 \text { days } \\
\text { after exposure to temperatures below } 50-55^{\circ} \mathrm{F} \\
\text { beginning with the older leaves. Remove } \\
\text { damaged leaves and move the plant to a } \\
\text { warmer location. }\end{array}$ \\
\hline $\begin{array}{l}\text { Older leaves lose some of their } \\
\text { color and terminal leaves become } \\
\text { chlorotic and sometimes even } \\
\text { dwarfed and deformed with } \\
\text { serrated edges. }\end{array}$ & Copper $(\mathrm{Cu})$ deficiency. & $\begin{array}{l}\text { Apply copper sulfate to soil surfaces at a rate } \\
\text { equivalent to } 1.5 \mathrm{lbs} \text { CuSO } / 1000 \mathrm{ft}^{2} \text {, or apply } \\
\text { copper sprays to foliage. To prevent, include } \\
\text { copper in the potting medium or use a periodic } \\
\text { micronutrient application. Roots are less able to } \\
\text { harvest copper from cold soil, so keep soil } \\
\text { temperatures above } 65^{\circ} \mathrm{F} \text {. }\end{array}$ \\
\hline $\begin{array}{l}\text { Leaves assume a more or less } \\
\text { vertical or low angle position } \\
\text { instead of a normal } 45 \text { to } 90 \text { degree } \\
\text { angle from the stem. Leaf color will } \\
\text { also be light or display a } \\
\text { washed-out appearance, and, in } \\
\text { extreme cases, leaf tips will be very } \\
\text { pale. }\end{array}$ & Excess heat and/or light. & $\begin{array}{l}\text { Prevent by providing the recommended light } \\
\text { and temperature levels. Leaves will return to } \\
\text { their normal position once light and temperature } \\
\text { levels are appropriate. Severely bleached } \\
\text { leaves may not fully recover. }\end{array}$ \\
\hline $\begin{array}{l}\text { The emerging terminal leaf has a } \\
\text { fishhook appearance. The new } \\
\text { leaf tip sometimes is obstructed } \\
\text { and caught by the succeeding leaf. }\end{array}$ & Bent-tip. & $\begin{array}{l}\text { This occurs when environmental and cultural } \\
\text { conditions that affect the growth rate of the plant } \\
\text { fluctuate. The greater the fluctuations, the more } \\
\text { severe bent-tip will become. Variations in light } \\
\text { levels, fertilizer, water regimes and } \\
\text { temperatures increase the incidence of bent-tip. } \\
\text { Maintain constant and consistent environmental } \\
\text { and cultural conditions to minimize this problem. }\end{array}$ \\
\hline $\begin{array}{l}\text { Tips of leaves turn brown and } \\
\text { brittle. }\end{array}$ & Tip burn. & $\begin{array}{l}\text { This is caused by high soluble salt levels in the } \\
\text { soil. Leach the soil, check soluble salt levels, } \\
\text { and reduce the fertilizer level. }\end{array}$ \\
\hline
\end{tabular}

